\title{
PENDIDIKAN ANAK DALAM PERSPEKTIF GENDER (STUDI KASUS PENDIDIKAN ANAK DI DESA KALIPANG KECAMATAN GRATI KABUPATEN PASURUAN)
}

\author{
Iwantoro, M.Pd \\ STIT Muhammadiyah Bangil \\ iwanalfarosi@gmail.com
}

\begin{abstract}
This study aims to determine the perceptions or opinions of parents or the community about children's education between girls and boys. In addition, it also reviews the factors that cause gender irregularities in children's education. This study used qualitative research by taking the location or object of research in Kalipang Village, Grati District, Pasuruan Regency, the informants were community members, community leaders, and village heads. The results of the study show that gender deviations occur in education, which means that parents or the community have a tendency to boys rather than girls in the field of education. Boys get more opportunities to get higher education than girls. The factors that cause gender irregularities are 1) relatively low level of community education, 2) relatively low economic level, 3) community stereotypes that regard women as weak creatures, and 4) social and cultural life in society that places women as beings whose activities are very limited.
\end{abstract}

Keywords: child education, gender perspective

\section{Pendahuluan}

Masalah gender selalu menarik untuk dikaji baik dari perspektif pendidikan, pekerjaan, status sosial, dan lain sebagainya. Perbedaan laki-laki dan perempuan secara fisiologis banyak menimbulkan gesekan-gesekan argumentasi dan aksi nyata di lapangan melalui demonstrasi-demonstrasi. Tidak jarang isu-isu gender ini menjadi bahan kajian panas di dewan, baik dalam bidang pendidikan, sosial ekonomi maupun lain-lain.

Membahas tentang sistem pendidikan Indonesia, kita masih dihadapkan pada kenyataan bahwa sistem pendidikan kita masih belum menjadi harapan akan pembebasan dari beragam ketertindasan, kekerasan, dan ketidakadilan. Padahal pendidikan adalah basis dari proses pencerahan, sebagai agen dan sarana memanusiakan manusia, atau kunci untuk memperoleh informasi yang bermanfaat bagi kehidupan manusia. Pendidikan tidak hanya bertujuan untuk membuat kita sukses (kaya) tetapi lebih dari itu pendidikan sangat diperlukan untuk merubah paradigma berpikir sehingga peradaban bangsa ini akan menjadi 
lebih baik.

Sebagian masyarakat kita memaknai bahwa pendidikan dikejar hanya untuk mendapatkan pekerjaan yang layak sehingga inilah yang menjadi cikal bakal terjadinya bias gender dalam pendidikan. Apalagi masyarakat di pedesaan yang masih menggangap bawah ruang gerak laki-laki dalam dunia kerja lebih banyak daripada perempuan. Asumsi kepatuhan kepada orang tua juga menjadi salah satu faktor bahwa perempuan sulit mendapatkan hak pendidikan seperti laki- laki. Ada sebagian masyarakat pula berasumsi bahwa anak laki-laki lebih banyak memiliki keunggulan dalam pendidikan, jurnal Muwazah menyampaikan beberapa ilmuan juga telah meneliti bagaimana perbedaan keahlian pada masing-masing bidang keilmuan pada tataran akademis. Dalam bukunya Santrock disebutkan beberapa hasil penelitian pada variable; keahlian matematika dan sains, kemampuan fisik, serta agresi dan regulasi diri, yang membedakan antara laki-laki dan perempuan. Hal ini untuk menjawab peryataanperyataan yang bias gender (Zaduqisti, 2009).

Pada keahlian bidang matematika dan sains ada temuan yang beragam dalam penelitian soal kemampuan tersebut. Dalam beberapa analisis, anak lakilaki lebih baik, namun secara keseluruhan, perbedaan gender dalam soal keahlian matematika ini cenderung lebih kecil. Pernyataan "laki-laki lebih unggul dibanding perempuan dalam bidang matematika" seharusnya tidak dipahami sebagai klaim bahwa semua laki-laki lebih unggul di atas perempuan dalam bidang matematika. Pernyataan itu sebaiknya dipahami sebagai pernyataan rata-rata. Juga tidak dalam semua penelitian menunjukan adanya perbedaan kemampuan ini, misalnya yang dilakukan oleh Coley pada tahun 2001, menunjukan bahwa tidak ada perbedaan antar kemampuan laki-laki dan perempuan pada kelas empat, delapan dan dua belas (Zaduqisti, 2009).

Pada dasarnya kaum perempuan dan laki-laki memang berbeda. Gender lebih ditekankan pada perbedaan peranan dan fungsi yang ada dan dibuat oleh masyarakat. Oleh karena itu, gender penting untuk dipahami dan dianalisa agar dapat melihat apakah perbedaan tersebut menimbulkan diskriminasi dalam artian perbedaan yang membawa kerugian dan penderitaan terhadap pihak perempuan. Sebenarnya, kita telah memiliki basis legal yang telah menjamin hak- 
hak dan kesempatan bagi laki-laki dan perempuan. Hal tersebut terlihat dari Deklarasi Penghapusan Kekerasan terhadap Perempuan yang dibuat oleh PBB pada tahun 1993. Namun, sayangnya deklarasi tersebut tidak begitu dikenal oleh masyarakat di Indonesia, sehingga jarang sekali digunakan sebagai acuan dalam kegiatan penyelesaian masalah yang berbasis gender.

Diskriminasi lebih sering terjadi pada masyarakat-masyarakat yang memiliki sumber daya kurang, baik sumber daya ekonomi maupun sumber daya manusia meskipun kadang-kadang faktor sosial dan budaya juga menyebabkan terjadi perbedaan perlakuan orang tua kepada anak perempuan dan lakil-lakinya. Sosialisasi keseteraan gender tersebut perlu terus dilakukan agar masyarakat benar-benar memahami.

Penelitian ini akan dilakukan di Desa Kalipang kecamatan Grati Kabupaten pasuruan. Desa Kalipang adalah salah satu desa yang banyak memiliki lembaga pendidikan mulai dari SD/MI sampai SMK/MA. Ketertarikan penulis untuk meneliti di Desa Kalipang ini tidak lepas dari banyaknya jumlah lembaga pendidikan di sana dan dekatnya jarak antar lembaga. Jumlah penduduk Desa Kalipang per Desember 2015 mencapai 8062 jiwa dengan 3871 jiwa laki-laki dan 4171 jiwa penduduk perempuan. Pekerjaan yang mendominasi adalah buruh tani dan petani dimana masing-masing mencapai 812 orang dan 720 orang (Profil Desa Kalipang, 2015).

Hasil observasi awal menunjukkan bahwa masih banyak terjadi kesenjangan dalam pendidikan antara anak laki-laki dan perempuan. Salah satu bentuk yang penulis temukan adalah menikahkan anak perempuan terlalu dini. Anak perempuan lulus sekolah dasar (SD) jika ada yang menginginkan (melamar) maka orang tua akan menikahkan. Tidak sedikit anak perempuan yang harus berhenti sekolah karena dinikahkan orang tuanya, terutama pada tingkat pendidikan menengah.

Berdasarkan hasil observasi awal tersebut peneliti ingin mengetahui bagaimana persepsi masyarakat terkait dengan pendidikan anak laki-laki dan anak perempuan. Adakah bias gender dalam pendidikan anak, jika ditemukan apa penyebab utama maupun penyebab lainnya sehingga dapat ditemukan solusi 
terbaik. Oleh karena itu peneliti mengangkat tema pendidikan anak dalam perspektif gender di Desa Kalipang Kecamatan Grati Kabupaten Pasuruan dalam penelitian hibah tahun 2018 ini.

Persepsi masyarakat terhadap pendidikan anak dalam penelitian ini adalah pendidikan dalam jenjang pendidikan menengah khususnya menengah atas sederajad. Keterangan atau maslah yang digali adalah bagaimana pesepsi masyarakat terhadap pendidikan anak laiki-laki dan perempuan serta apa saja faktor-faktor yang menyebabkan terjadinya bias atau ketimpangan gender terhadap pendidikan anak di Desa Kalipang Kecamatan Grati Kabupaten Pasuruan.

\section{Tinjauan Pustaka}

\section{Konsep Tentang Pendidikan Anak}

Tokoh pendidikan nasional atau bapak pendidikan kita; Ki Hajar Dewantara mengenalkan Tri Pusat Pendidikan yang harus diberikan kepada anak. Tri pusat pendidikan adalah tiga pusat pendidikan yang meliputi; pendidikan dalam keluarga, pendidikan dalam sekolah, dan pendidikan dalam masyarakat.

a. Pendidikan dalam keluarga

Dalam keluarga pendidikan merupakan tempat proses pembelajaran meskipun dalam skala yang terbatas. Keluarga adalah unit terendah dalam proses pendidikan anak, di mana unsur-unsur penting dapat ditanamkan kepada anak menuju pendewasaaan.

b. Pendidikan dalam sekolah

Sekolah adalah jalur terstruktur dan formal yang memberikan pelayanan pendidikan kepada anak. Di mana pendidikan di sekolah ini terdiri dari jenjang pendidikan dasar, menengah, dan tinggi. Sekolah bertujuan membimbing, mengarahkan, dan mendidik sehingga lembaga tersebut menghendaki kehadiran kelompok-kelompok umur tertentu dalam ruang-ruang kelas yang dipimpin oleh guru untuk mempelajari kurikulum bertingkat tersebut. 


\section{c. Pendidikan dalam masyarakat}

Manusia merupakan makhluk yang memiliki keinginan untuk menyatu dengan sesamanya serta alam lingkungan di sekitarnya. Dengan menggunakan pikiran, naluri, perasaan, keinginan dan sebagainya manusia memberi reaksi dan melakukan interaksi dengan lingkungannya. Pola interaksi sosial dihasilkan oleh hubungan yang berkesinambungan dalam suatu masyarakat (Kurniawan, 2015).

Sebagai manusia yang sempurna pendidikan mutlak dilaksanakan, dalam kehidupan ini pendidikan harus dilakukan sepanjang hayat. Proses pendidikan adalah long life education yang di masyarakat dikatakan sebagai pendidikan tanpa akhir.

Apabila dilihat dari segi kemampuan dasar pedagogik, manusia dipandang sebagai Homo edukandum, makhluk yang harus dididik atau bisa disebut animal educabil, makhluk sebangsa binatang yang bisa dididik. Manusia itu sendiri tidak dapat terlepas dari potensi psikologis yang dimilikinya secara individual berbeda dalam abilitas dan kapasitasnya dari kemampuan individual manusia lainnya. Dengan berbeda-bedanya kemampuan untuk dididik itulah fungsi pendidikan pada hakikatnya adalah melakukan seleksi melalui proses kependidikan atas diri pribadi manusia. Proses seleksi tersebut menuju kepada dua arah, yaitu: (1) menyeleksi bakat dan kemampuan apa saja yang dimiliki manusia, untuk selanjutnya dikembangkan melalui proses kependidikan, dan (2) menyeleksi sampai di manakah kemampuan manusia dapat dikembangkan guna melaksanakan tugas hidupnya dalam hidup bermasyarakat (Arifin, 2012: 54).

Dengan demikian dapat diketahui dan diramalkan titik maksimal perkembangan yang akan menjadikan anak survive dalam masyarakat yang senantiasa berkembang. Dengan kata lain, proses pendidikan bagi manusia adalah usaha yang sistematis dan berencana untuk menyeleksi kemampuan belajar manusia agar dapat berkembang sampai pada titik optimal kemampuannya, yaitu kemampuan mengembangkan potensi kapabilitasnya semaksimal mungkin melalui proses belajar-mengajar (Arifin, 2012: 54). 
Pendidikan bagi anak sangat penting, dalam kaitannya untuk menyiapkan anak-anak untuk mengarungi kehidupan selanjutnya. Sekaligus dengan pendidikan tersebut anak dipandu dan diarahkan dalam prose pertumbuhan dan perkembangannya sehingga menjadi manusia yang utuh jasmani dan rohaninya.

\section{Kesetaraan Gender dalam Pendidikan}

Gender adalah sebuah sifat yang melekat pada kaum laki-laki maupun kaum perempuan yang dikonstruksi secara sosial maupun kultural. Contohnya adalah bahwa perempuan itu dikenal lemah lembut, cantik, emosional, dan keibuan. Sedangkan laki-laki dianggap kuat, rasional, perkasa, dan jantan. Ciri dan sifat itu sendiri merupakan sifat-sifat yang dapat dipertukarkan. Artinya ada laki-laki yang emosional. Lembah lembut, keibuan, sementara ada juga perempuan yang kuat, rasional, dan sejenisnya. Perubahan ciri-ciri dari sifat itu dapat terjadi dari waktu ke waktu serta dari satu tempat ke tempat yang lain. Misalnya saja zaman dahulu di suatu suku tertentu perempuan lebih kuat dari laki- laki akan tetapi pada zaman lain dan di tempat yang berbeda laki-laki yang lebih kuat. Semua hal yang dapat dipertukarkan antara sifat perempuan dan laki-laki, yang bisa berubah dari waku ke waktu serta berbeda dari satu tempat ke tempat yang lain maupun berbeda dari suatu kelas ke kelas yang lain, itulah yang dinamakan dengan konsep gender (Faqih, 2008: 8).

Gender merupakan seperangkat peran seperti halnya kostum dan topeng teater, menyampaikan kepada orang lain bahwa kita adalah feminim atau maskulin (Mosse, 1993: 3). Perilaku khusus tersebut mencakup penampilan, pakaian, sikap, kepribadian, bekerja di dalam maupun di luar rumah tangga, seksualitas, tanggung jawab keluarga dan lain sebagai yang secara bersamaan memoles peran gender kita. Kita mulai mempelajari peran gender sejak dari lahir, dimana kaum ibu biasanya diundang untuk bermain dengan bayi orang lain yang kemudian didandani sebagai anak perempuan ataupun anak laki-laki. Tidak hanya gender dari seorang bayi yang dapat menimbulkan berbagai macam tanggapan dari kaum perempuan, namun 
perilaku yang serupa dari seorang bayi yang ditanggapi secara berbeda-beda. Ketika seorang bayi didandani sebagai laki-laki, maka kaum perempuan akan menanggapi inisiatif bayi dengan aksi fisik dan permainan. Namun, ketika bayi yang sama tampak seperti perempuan dan melakukan hal yang sama, kaum perempuan itu menenangkan dan menghiburnya.

Konsep kesetaraan gender adalah kondisi dimana laki-laki dan perempuan memiliki kesamaan hak dan kewajiban yang terwujud dalam kesempatan, kedudukan, peranan yang dilandasi sikap dan perilaku saling bantu membantu dan saling mengisi di semua aspek kehidupan. Kesetaraan gender berarti kesamaan kondisi bagi laki-laki dan perempuan dalam mendapatkan kesempatan serta hak-haknya sebagai manusia, agar mampu berperan serta dalam kegiatan politik, ekonomi, hukum, sosial budaya, pendidikan serta pertahanan dan keamanan nasional.

Di Indonesia, kesetaraan gender selalu menjadi isu yang menarik untuk diperbincangkan setiap tahunnya. Pada saat memperingati Hari Kartini dimana momen ini sangat tepat untuk melakukan penilaian apakah emansipasi kaum perempuan dan kesetaraan gender telah dicapai oleh Indonesia. Persoalan perempuan berkaitan dengan masalah kesetaraan gender memang dapat mengundang rasa simpati yang cukup besar dari masyarakat luas. Hal tersebut terjadi karena permasalahan kesetaraan gender sering dianggap erat kaitannya dengan persoalan keadilan sosial dalam arti yang lebih luas, yaitu isu-isu yang berkisar pada masalah kesenjangan orang kaya dan miskin hingga ketimpangan ekonomi antara negara kaya dan miskin hingga ketimpangan ekonomi antara negara kaya dan miskin. Namun, kesetaraan gender ini juga dapat mengundang rasa ambivalensi bahkan antipati baik dari kelompok aktivis perempuan maupun dari masyarakat umum.

Pada dasarnya kaum perempuan dan laki-laki memang berbeda. Gender lebih ditekankan pada perbedaan peranan dan fungsi yang ada dan dibuat oleh masyarakat. Oleh karena itu, gender penting untuk dipahami dan dianalisa agar dapat melihat apakah perbedaan tersebut menimbulkan diskriminasi dalam 
artian perbedaan yang membawa kerugian dan penderitaan terhadap pihak perempuan. Sebenarnya, kita telah memiliki basis legal yang telah menjamin hak-hak dan kesempatan bagi laki-laki dan perempuan. Hal tersebut terlihat dari Deklarasi Penghapusan Kekerasan terhadap Perempuan yang di buat oleh PBB pada tahun 1993. Namun, sayangnya deklarasi tersebut tidak begitu dikenal oleh masyarakat di Indonesia, sehingga jarang sekali digunakan sebagai acuan dalam kegiatan penyelesaian masalah yang berbasis gender.

Pada kenyataannya di lapangan sering terjadi diskriminasi terhadap perempuan. Terlebih dalam bidang pendidikan orang tua lebih memberikan akses kepada anak laki-laki dari pada kepada anak perempuannya, khususnya di daerah pedesaan.

\section{Ketidakadilan Gender}

Berbicara tentang ketidakadilan dalam perspektif ini pasti tidak lepas dengan istilah diskriminasi. Pasal 1 ayat 3 Undang-undang Nomor 39 Tahun 1999 tentang Hak Asasi Manusia, menjelaskan bahwa pengertian diskriminasi adalah setiap pembatasan, pelecehan, atau pengucilan yang langsung maupun tak langsung didasarkan pada perbedaan manusia atas dasar agama, suku, ras, etnik, kelompok, golongan, status sosial, status ekonomi, jenis kelamin, bahasa, keyakinan politik, yang berakibat pengangguran, penyimpangan atau penghapusan pengakuan, pelaksanaan atau penggunaan hak asasi manusia dan kebebasan dasar dalam kehidupan baik individual maupun kolektif dalam bidang politik, ekonomi, hukum, sosial, budaya dan aspek kehidupan lainnya.

Menurut Theodorson \& Theodorson, diskriminasi adalah perlakuan yang tidak seimbang terhadap perorangan atau kelompok berdasarkan sesuatu. Biasanya bersifat kategorial atau atribut-atribut khas, seperti berdasarkan ras, kesukubangsaan, agama atau keanggotaan kelas-kelas sosial. Istilah tersebut biasanya untuk melukiskan suatu tindakan dari pihak mayoritas yang dominan dengan minoritas yang lemah, sehingga dapat dikatakan bahwa perilaku mereka itu bersifat tidak bermoral dan tidak demokratis (Fulthoni, 2009: 3). 
Fakta-fakta yang dapat kita lihat di seluruh dunia bahwa memang menunjukkan adanya ketidakseimbangan besar antara perempuan dan laki-laki. Adanya ketertinggalan perempuan mencerminkan masih adanya ketidakadilan dan ketidaksetaraan antara laki-laki dan perempuan di Indonesia, hal tersebut dapat kita dari gambaran kondisi perempuan di Indonesia. Jika kita ingin memahami manusia yang mendiami bumi ini dan hal tersebut dianggap semakin penting dikarenakan hanya dengan pemahaman tersebut yang akan memungkinkan manusia untuk menyelesaikan berbagai masalah yang dihadapinya, maka mau tidak mau perempuan yang jelas berbeda dengan lakilaki dan berjumlah lebih dari separuh penduduk bumi, maka harus dipahami secara tepat.

Sekalipun terdapat berbagai konsep yang baik tentang perempuan, namun dalam praktiknya hanya terdapat satu kenyataan, yaitu perempuan berada di bawah dominasi laki-laki. Kaum laki-laki yang membangun dunia dimana terdapat perempuan di dalamnya atau dengan kata lain, laki-laki dan perempuan itu tidak setara. Kedudukan kaum perempuan dan peranannya di Indonesia dalam berbagai bidang kehidupan dan di semua kelompok etnis dikupas, tidak lepas dari permasalahan-permasalahan tersebut. Sesungguhnya perbedaan gender dengan pemilahan sifat, peran dan posisi tidak menjadi masalah sepanjang tidak melahirkan ketidakadilan. Namun, pada kenyataannya perbedaan gender telah melahirkan berbagai ketidakadilan, bukan hanya bagi kaum perempuan, tetapi juga bagi kaum laki-laki.

Pada dasarnya laki-laki dan perempuan memang berbeda dan pada kajian biologis tidak bisa disetarakan. Laki-laki terlahir dengan kodrat kelelakiannya yang tidak mungkin disamakan dengan perempuan. Hanya dalam peran dan fungsinya di masyarakat kesetaraan dan kesempatan harus diberikan ruang yang luas kepada perempuan. Keterlibatan dalam ruang publik perlu diberikan kepada mereka. Oleh karena itu gender ini perlu dipahami dan dianalisa secara baik sehingga tidak menimbulkan diskriminasi atau 
ketidakadilan yang secara langsung atau tidak langsung akan merugikan kepada perempuan.

\section{Bentuk-Bentuk Ketidakadilan Akibat Diskriminasi Gender}

\section{Marginalisasi}

Menurut Mansur Faqih, proses marginalisasi sama saja dengan proses pemiskinan. Hal ini dikarenakan tidak diberinya kesempatan kepada pihak yang termarginalkan kepada dirinya. Demikian juga yang dialami oleh perempuan saat proses marginalisasi ini terjadi pada jenis kelamin. Perempuan merupakan pihak yang dirugikan daripada laki-laki dalam ketidakadilan gender ini. Sebagai contoh dalam pekerjaan, perempuan yang bekerja dianggap hanya untuk memberikan nafkah tambahan bagi keluarga, maka perbedaan gaji pun diterapkan antara perempuan dan laki-laki (Faqih, 2008: 13).

Dalam dunia pendidikan seringkali perempuan mengalami hal ini. Perempuan identik dengan pekerjaan di rumah; dapur dan kasur. Artinya perempuan hanya akan beraktifitas di dapur memasak dan melayani suami, pemahaman seperti ini yang sering dijumpai di pedasaan. Entah karena faktor sumber daya manusia atau faktor ekonomi.

\section{Subordinat Perempuan Dalam Sosial dan Budaya}

Pandangan gender ternyata tidak saja berakibat terjadinya marginalisasi, akan tetapi juga mengakibatkan terjadinya subordinasi terhadap perempuan. Akar dari subordinasi atas perempuan adalah budaya patriarchal. Budaya patriarchal adalah budaya yang menomorsatukan laki-laki, atau berpusat pada laki-laki dan mengesampingkan perempuan. Laki-laki dipandang sebagai makhluk yang primer dan perempuan sebagai yang sekunder. Di dalam budaya patriarcha/cara memandang realitas adalah dari sudut pandang laki-laki dalam memandang keberadaan perempuan. Singkatnya, masyarakat yang berhaluan patriarchal melihat perempuan sebagai makhluk yang inferior, di mana semua penilaian tersebut berkaitan dengan tubuhnya.

Pembagian kerja yang dikotomis, yaitu menempatkan perempuan di 
sektor domestik dan laki-laki di sektor publik sehingga laki-laki memiliki akses ke arah ekonomi, sosial, politik dan informasi yang lebih besar dibandingkan perempuan. Hubungan asimetris ini dapat memantul ke segala arah aspek kehidupan perempuan yang dapat menyebabkan perempuan tersubordinat sekaligus terlemahkan (Prantiasih, 2012).

\section{Stereotip Terhadap Perempuan}

Dalam sebuah masyarakat selalu terdapat indikasi adanya pelabelan sifat (stereotyping) yang diletakan kepada laki-laki dan perempuan yang dikontruksi secara sosial maupun budaya, yang turut mempengaruhi pembentukan representasi terhadap perempuan dan laki-laki (Iswari, 2010: 21). Melalui stereotip masyarakat mendistribusikan tugas laki-laki dan perempuan di dalam masyarakat. Stereotip mulai dari yang terkecil yaitu keluarga, nilai dalam ajaran agama, dan pada masa kini stereotip terus terpelihara dan meluaskan pengaruhnya melalui media dan propaganda (Boangmanalu, 2012: 19).

Stereotype berarti pemberian citra/label kepada seseorang atau kelompok yang didasarkan pada anggapan yang salah. Stereotip ini memproyeksikan pola pikir masyarakat pada diri perempuan. Citra yang diberikan pada perempuan ialah sebagai sosok yang sabar dan telaten. Hal ini memposisikan perempuan dalam setiap tradisi atau upacara keagamaan yang selalu menempatkan perempuan pada urusan domestik seperti memasak, membuat dan menyiapkan sesaji. Anggapan lain, yaitu menganggap bahwa perempuan merupakan seseorang yang lemah lembut dan kurang bersikap tegas. Pada posisi yang berbeda, hierarki gender menempatkan laki-laki sebagai sosok yang perkasa, selalu menang, tidak pernah menangis, dan bertanggungjawab penuh secara publik, bukan secara domestik. Hal inilah yang membuat orang-orang di luar hierarki (perempuan) menjadi kesulitan untuk diterima dalam nilai-nilai tersebut. 


\section{Kekerasan Gender}

Kekerasan adalah serangan atau invasi terhadap fisik maupun integrasi mental psikologis seseorang. Kekerasan terhadap sesama manusia pada dasarnya muncul dari berbagai sumber, namun salah satu kekerasan yang terjadi terhadap satu jenis kelamin tertentu disebabkan oleh anggapan gender. Adapun yang tergolong pada kekerasan gender diantaranya adalah tindakan pemukulan dan serangan fisik, pemerkosaan terhadap perempuan, kekerasan dalam bentuk fornografi, dan kekerasan yang paling umum dilakukan di tengah masyarakat yakni bentuk pelecehan seksual (Rohmania, 2014: 25).

\section{Faktor-Faktor Penyebab Bias Gender Dalam Pendidikan}

Bias gender ini tidak hanya berlangsung dan disosialisasikan melalui proses dan sistem pembelajaran di sekolah, tetapi juga melaluin pendidikan dalam lingkungan keluarga dan masyarakat. Stereotip gender yang berkembang di masyarakat telah membagi peran-peran yang pantas untuk laki-laki dan perempuan. Nilai dan sikap yang dipengaruhi oleh faktor-faktor sosial budaya masyarakat yang secara melembaga telah memisahkan gender ke dalam peran yang berlainan inilah yang meyebabkan ketidaksetaraan gender terlembaga pula dalam kehidupan bermasyarakat. Suleman (dalam Rahmi dan Habibullah) menyebutkan bahwa hal pokok yang menjadi alasan terjadinya ketidaksetaraan gender adalah; 1) semakin tinggi pendidikan formal semakin terbatas jumkah sekolah yang tersedia, 2) semakin tinggi pendidikan semakin mahal biaya sekolah, dan 3) infestasi dalam pendidikan juga seringkali tidak dapat mereka rasakan karena anak perempuan menjadi anggota keluarga setelah mereka menikah (Wita, 2018).

\section{Metode Penelitian}

Penelitian ini menggunakan pendekatan kualitatif, peneliti ingin menggambarkan obyek penelitian seobyektif mungkin. Pendekatan kualitatif yang digunakan adalah pendekatan kualitatif studi kasus. Penelitian ini berusaha mengetahui sedalam-dalamnya tentang bagaimana perspektif gender dalam 
pendidikan anak laki-laki maupun anak perempuan. Bagaimana masyarakat memberikan peluang yang besar kepada anak-anaknya dalam memperoleh pendidikan. Orang tua seharusnya memberikan akses atau kesempatan yang sama terhadap anak-anaknya untuk memperoleh pendidikan yang baik, apalagi di era sekarang dengan semakin sengitnya persaingan di dunia kerja sehingga orang tua seharusnya memberikan bekal yang cukup dalam hal pendidikan kepada anak-anaknya baik laki-laki maupun perempuan.

Sumber data dalam penelitian ini meliputi sumber data primer dan sekunder. Sumber data primer terdiri dari masyarakat/orang tua, tokoh masyarakat, dan kepala desa/perangkat desa sebagai informan. Sedangkan sumber data sekunder berupa dokumen-dokumen pendukung seperti profil desa. Peneliti menggunakan teknik triangulasi untuk menguji keabsahan data.

\section{Pembahasan}

\section{Persepsi masyarakat Desa Kalipang Grati Pasuruan terhadap pendidikan anak laki-laki dan anak perempuan}

Masyarakat memberikan perhatian yang sama terhadap anak-anaknya baik perempuan maupun laki-laki. Masyarakat menyadari bahwa anak adalah titipan Allah yang harus dijaga, oleh karena itu mereka memberikan porsi yang seimbang kepada keduanya. Inilah pendidikan keluarga yang diberikan oleh orang tua kepada anak-anaknya. Bimbingan, motivasi, dan nasehat diberikan kepada anak tanpa memandang jenis kelaminnya. Penanaman nilai-nilai keagamaan diberikan orang tua kepada mereka secara proporsional sebagai bentuk tanggung jawab orang tua.

Dalam hal pendidikan di sekolah atau formal, masyarakat lebih cenderung memberikan kesempatan kepada anak laki-lakinya dari pada anak perempuannya. Anak perempuan lebih diberikan prioritas untuk mendapat pendidikan nonformal atau mondok di sebuah pondok pesantren. Anak perempuan paling tinggi di sekolahkan pada tingkat sekolah menangah atas (SMA) sederajad bahkan ada yang sampai sekolah menengah pertama (SMP) 
sederajad kemudian dinikahkan, meskipun pada dasarnya orang tua ingin menyekolahkan pada jenjang yang lebih tinggi.

Aktivitas anak perempuan di masyarakat oleh orang tua lebih dibatasi daripada anak laki-laki. Orang tua lebih menjaga anak perempuannya agar lebih banyak beraktivitas dalam rumah. Aktivitas-aktivitas di bidang agama masih diizinkan oleh orang tua, seperti kegiatan muslimatan, dan sejenisnya. Sedangkan untuk kegiatan kemasyarakatan lainnya seperti karang taruna orang tua tidak memberikan izin untuk berperan aktif didalamnya. Masyarakat berasumsi bahwa anak perempuan akan lebih "aman" jika beraktivitas dalam rumah dan kontrol orang tua lebih baik.

Kesimpulan yang dapat ditarik adalah masyarakat Desa Kalipang masih berpersepsi bahwa pendidikan anak laki-laki lebih utama daripada anak perempuan. Ada kecenderungan bahwa anak laki-laki lebih mendapat kesempatan yang lebih besar daripada anak perempuan, masyarakat/orang tua lebih mengutamakan anak laki-lakinya untuk mendapat pendidikan yang lebih tinggi. Meskipun secara umum masyarakat memberikan perhatian yang sama kepada anak-anaknya baik perempuan maupun laki-laki karena mereka menganggap bahwa anak adalah titipan Allah yang harus dijaga, akan tetapi pada prakteknya anak laki-lakilah yang mendapatkan kesempatan yang lebih besar.

\section{Faktor Yang Menyebabkan Terjadinya Bias atau Ketimpangan Gender Terhadap Pendidikan Anak di Desa Kalipang Grati Pasuruan}

Terjadinya ketimpangan/bias gender terhadap pendidikan anak di Desa Kalipang Kecamatan Grati Kabupaten Pasuruan setidaknya disebabkan oleh beberapa faktor, antara lain:

1. Tingkat pendidikan masyarakat

Sumber Daya Manusia (SDM) yang masih tergolong kurang dengan ditunjukkan dengan tingkat pendidikan masyarakat yang masih minim adalah faktor yang menyebabkan terjadinya bias gender dalam pendidikan anak. 
Mayoritas pendidikan masyarakat Desa Kalipang adalah pendidikan dasar sederajat membuat pola pikir mereka sederhana.

2. Tingkat ekonomi masyarakat

Sebagian besar masyarakat Desa Kalipang berkerja sebagai petani, buruh tani, pedagang kecil, dan wiraswasta. Penghasilan yang didapat pun masih tergolong kecil untuk membiayai pendidikan anak-anaknya. Pendapatan sehari-hari lebih dipergunakan untuk menutup kebutuhan keluarga sedangkan untuk sektor pendidikan menjadi hal kurang diprioritaskan. Bantuan dari pemerintah melalui program-program unggulannya seperti Kartu Indonesia Pintar (KIP), Program Keluarga Harapan (PKH), dan Bantuan Operasional Siswa (BOS), belum sepenuhnya cukup untuk menutup kekurangan sektor pendidikan. Sekolah-sekolah tidak sepenuhnya gratis sehingga meskipun ada bantuan pemerintah (BOS) untuk siswa tetap saja masyarakat masih menambahkan atau menyisihkan keuangan untuk itu. Ketika PKH cair pun lebih banyak digunakan untuk menutup kebutuhan keluarga sehari-hari atau kebutuhan sekunder lainnya.

3. Stereotip terhadap anak perempuan

Masih berkembangnya stereotip di masyarakat bahwa anak perempuan adalah anak yang lemah sehingga tidak sesuai mereka beraktivitas/bekerja di luar rumah menjadi salah satu sebab terjadinya bias gender terhadap pendidikan anak perempuan. Di Desa Kalipang mayoritas anak perempuan memang beraktivitas di sekitar rumah, seperti membantu orang tua di kebun/sawah, mencari makanan ternak, dan sejenisnya. Aktivitas seperti itu sudah menjadi pemandangan yang biasa, kalaupun ada yang bekerja di luar biasanya menjadi karyawan perusahaan yang ada di sekitar desa. Stereotip sperti ini yang menyebabkan perempuan tertinggal dengan laki-laki dalam segala hal termasuk dalam memperoleh kesempatan pendidikan.

4. Sosial dan budaya

Budaya di masyarakat bahwa jangkauan perempuan terbatas pada "sumur, dapur, dan kasur" yang mengakar kuat menjadi faktor yang menyebabkan anak perempuan mengalami kecenderungan diskriminasi 
dalam pendidikan. Aktivitas perempuan yang terbatas tersebut membuat orang tua berpikir dua kali untuk memberikan investasi pendidikan yang lebih tinggi untuk anak perempuannya. Pondok pesantren biasanya menjadi pilihan orang tua untuk pendidikan anaknya, sambil menunggu "jodoh" anak tersebut. Di masyarakat berkembang pantang menolak lamaran laki-laki untuk anak perempuannya, meskipun anak masih dalam proses sekolah. Orang tua lebih menikahkan anak perempuannya daripada menunggu si anak menyelesaikan sekolahnya sampai tuntas. Pemikiran-pemikiran yang sederhana dan masih kuatnya budaya di masyarakat seperti ini membuat anak perempuan menjadi kalah dengan anak laki-laki. Mainset atau pola pikir masyarakat yang seperti ini sulit untuk diluruskan kerena berbagai faktor penyebab saling terkait. 


\section{DAFTAR PUSTAKA}

Arifin, Muzayyin. 2012. Filsafat Pendidikan Islam. Jakarta: Bumi Aksara.

Boangmanalu, Abby Gina. 2012. Identitas Perempuan: Siapakah Yang Memberi? Analisa Kritis Atas Identitas Gender. Skripsi. FIB UI.

Fakih, Mansour. 2008. Analisis Gender \& Tranformasi Sosial. Yogyakarta: Pustaka Pelajar.

Fulthoni. 2009. Buku Saku Untuk Kebebasan Beragama Memahami Diskriminasi. Jakarta: The Indonesian Legal Resource Center.

Iswari, Ery. 2010. Perempuan Makassar: Relasi Gender Dalam Folklor. Yogyakarta: Ombak.

Kurniawan, Machfud I. 2015. Tri Pusat Pendidikan Sebagai Sarana Pendidikan Karakter Anak Sekolah Dasar. Journal Pedagogia Vol. 4 No. 1 Februari.

Mosse, Julia Cleves. 1993. Gender dan Pembangunan. Yogyakarta: Pustaka Pelajar.

Prantiasih, Arbaiyah. 2012. Hak Asasi manusia. Jurnal pendidikan Pancasila dan Kewarganegaraaan, Tahun 25 No. 1.

Rohmaniyah, Inayah. 2014. Konstruksi Patriarki Dalam tafsir Agama: Sebuah Jalan Panjang. Yogyakarta: Diandra Pustaka Indonesia.

Wita, Gusmira. (2018). Bias Gender Dalam Pendidikan. https://www.kompasiana.com/gusmira/59008f4ff07a617f2fa71cf5.

Diakses pada tanggal 12 Nopember 2018 jam 10.58 WIB.

Zaduqisti, Esti. (2009). Stereotipe Peran Gender Bagi Pendidikan Anak. Muzawah Vol. 1 No. 1 Januari-Juni. 